\title{
SPATIAL ANALYSIS AND THE DETERMINANTS OF MOSQUITO VECTOR OF FILARIASIS IN THE ENDEMIC AREAS OF WEST SUMATERA
}

\author{
Masrizal1), Fivi Melva Diana'2), Rosfita Rasyid3) \\ 1) Study Program in Public Health, \\ Faculty of Public Health, Andalas University \\ 2) Study Program in Nutrition, Faculty of Public Health, Andalas \\ University \\ 3) Departement of Public Health, Faculty of Medicine, Andalas University
}

\begin{abstract}
BACKGROUND: Filariasis is an infectious disease caused by filarial worm (Wuchereriabancrofti, Brugiamalayi and Brugiatimori). It is transmitted by mosquito vector. Agam and West Pasaman are hyperendemic areas of filariasis in West Sumatra, with prevalence of 11.27 cases per 100,000 population, and 12.40 cases per 100,000 population, respectively. The environmental condition consists of mountain, plain, river, lake, plantation, and rice field. This study aimed to determine the risk factors associated with the incidence of filariasis and to implement the use of geographic information system for mapping the vulnerability of area in West Sumatra.
\end{abstract}

SUBJECT AND METHODS: This was case control study, conducted in Agam and West Pasaman districts, West Sumatera. A sample of 74 cases and 74 controls was selected for this study. Both study groups were matched by age and sex. Spatial and multivariate analyses were employed for data analysis.

RESULTS: In Agam district, the type of vector was Culex (67.26\%), Aedes (18.06\%), Armigeres (14.19\%), and Anopheles (0.48\%). In West Pasaman district, the type of vector was Culex (70.25\%), Aedes (20.25\%), Armigeres (08.19\%) and Anopheles (1.31\%). In Agam and West Pasaman districts, the risk factors of filariasis included lack of knowledge (the strongest risk factor in Agam), absence of wire net, hanging out in the evening, use of mosquito bed net, absence of chemical insecticide, open clothes, presence of animal reservoir, living near plantation, paddy, river, marsh, shrub, and use of house ceiling (the strongest in West Pasaman). In Agam clustering of filariasis was found Subang, Muaro Putuih, Sungai Aur, Nagari Air Haji, Binjai, and the Crossing Valley.

CONCLUSION: The strongest risk factor of filariasis in Agam is the lack of knowledge. The strongest risk factor of filariasis in West Pasaman is the use house ceiling. The most common type of filarial vector in Agam and West Pasaman is Culex.

Keywords: Geographic Information System, filariasis, risk factor, vulnerabilities, Agam, West Pasaman. 